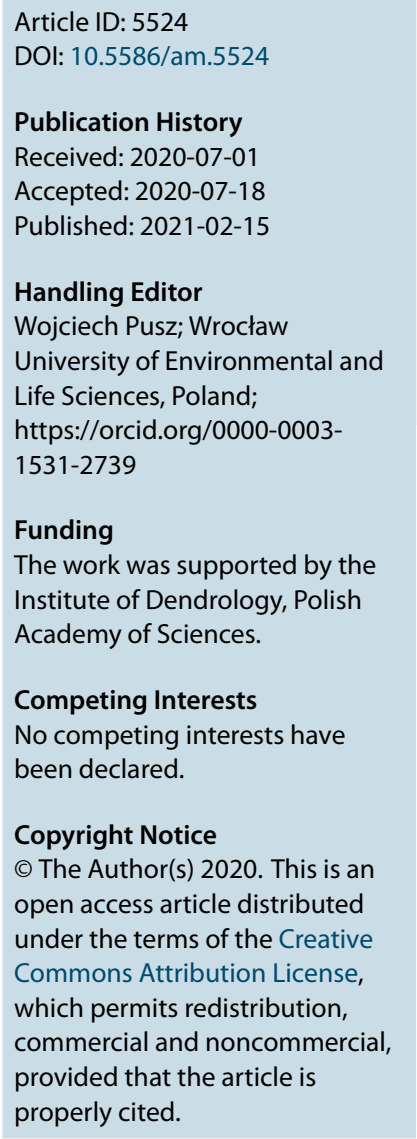

MEMORIES AND SCIENTISTS

\section{Professor Maria Rudawska}

\author{
Tomasz Leski $\mathbb{1}^{*}$ \\ Institute of Dendrology, Polish Academy of Sciences, Parkowa 5, Kórnik, 62-035, Poland
}

*To whom correspondence should be addressed. Email: tleski@man.poznan.pl

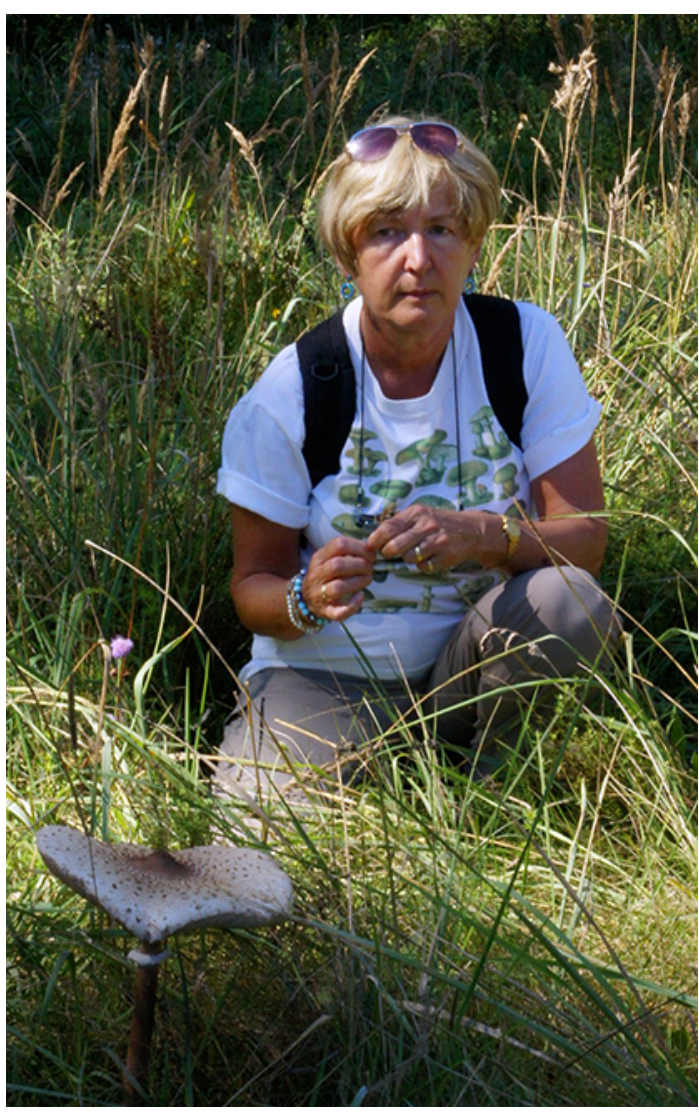

Maria Rudawska was born on June 17, 1949, in Ostrów Wielkopolski, where she lived until she completed her primary and secondary education. In 1967, she began studying biology at the Faculty of Biology and Earth Sciences at the Adam Mickiewicz University in Poznań. In 1971, she received a scholarship funded by the Department of Dendrology (now Institute of Dendrology), Polish Academy of Sciences, in Kórnik. In 1972, based on her work, Nitrogen Fractions and Reducing Sugars in Isolated Lupine Cotyledons written under the supervision of Dr. Aleksandra Hoffmann from the Department of Plant Physiology, Prof. Rudawska received a master's degree in biology with an emphasis in botany. She started working at the Institute of Dendrology immediately after graduating, and Kórnik became her new home. She has spent the entire path of her scientific career at the Institute of Dendrology; her scientific experience in mycological studies comes from nearly five decades of work at the Institute.

In 1974, she became an assistant at the Laboratory of Tree Physiology headed by Professor Mirosław Tomaszewski. At that time, Prof. Rudawska’s scientific relationships included Prof. Roman Pachlewski, from the Forest Research Institute, who introduced her to the fascinating world of mycorrhizal fungi, after which she enthusiastically took up research on the physiology of forest tree mycorrhiza (mainly Scots pine). She also worked on a research topic headed by Prof. Tomaszewski, "Poplar resistance to infection caused by the fungus Dothichiza populea", financed 
by the Polish-American Marie Skłodowska-Curie Foundation. In subsequent years, she began research on the synthesis of auxins and cytokinins by various mycorrhizal fungal symbionts of Scots pine in relation to nitrogen and phosphorus nutrition. This issue was the basis of her doctoral dissertation titled The Effect of Mineral Nutrition on the Auxins and Cytokinins Production in Pine Mycorrhiza prepared under the supervision of Prof. Tomaszewski. The defence of her doctoral dissertation took place in December 1981 at the Faculty of Biology and Earth Sciences at the Adam Mickiewicz University in Poznań during the first days of martial law. Professor Rudawska remembers her PhD thesis defence as a very abnormal situation, riddled with fear and anxiety.

In 1983, during her 4-month internship, Prof. Rudawska stayed at the Institute of Plant Protection in Merelbeke, Belgium, where she became acquainted with the biochemical mechanisms of the antagonistic properties of the fungi Trichoderma viride and T. harzianum in relation to certain pathogens. After returning, she continued this research along with studies on mycorrhiza and mycorrhizal fungi. In the following years of her scientific career, Prof. Rudawska continued to explore factors regulating the establishment of mycorrhizal symbiosis. Some of her research in this field was carried out during her two half-year internships, 1987-1988 and 1993-1994, at Claude Bernard University in Lyon, France, in cooperation with Dr. Gilles Gay and Dr. Jean-Claude Debaud. The research conducted in France examined the role of auxins and enzymes of nitrogen metabolism in the process of mycorrhiza formation, including ectomycorrhizal and ectendomycorrhizal fungi. In some studies, she used a genetically transformed strain of the Hebeloma cylindrosporum with auxin overproduction as a model organism. Professor Rudawska summarized the results of these studies in her postdoctoral dissertation titled, The Key Factors Affecting Mycorrhizal Symbiosis of Scots Pine Seedlings, defended in 1998, at Nicolaus Copernicus University in Toruń.

Nothing in nature is immutable, and Prof. Rudawska's scientific interests continued to evolve. After an intensive period of physiological research on ectomycorrhiza, she switched her attention to the problem of forest decline and the role of mycorrhizae and mycorrhizal fungi in this process. Her work in this area included laboratory and field studies. Laboratory experiments focused on the effects of low $\mathrm{pH}$ and increased aluminum ion content on the growth of ectomycorrhizal fungi and the functioning of mycorrhizal symbiosis. In the field studies, she analyzed the impact of environmental pollution from different sources, in particular, copper and aluminum smelters, phosphate fertilizer plants, and the urban-industrial area of Kraków, on the diversity and species composition of communities of ectomycorrhizal fungi associated with forest trees.

Professor Rudawska's participation in the 1998 Second International Conference on Mycorrhizae, held in Uppsala, Sweden, inspired the introduction of molecular methods to identify mycorrhizal fungi from environmental samples. With her research team, Professor Rudawska was one of the first mycologists in Poland to introduce such analyses as a standard technique. Over time, it turned out to be a right step; molecular analysis techniques have greatly advanced the identification of fungal species, even from a single ectomycorrhizal root tip. Identification of ectomycorrhizas based on the sequencing of fungal ITS rDNA allowed Prof. Rudawska's team to develop intensive research on ectomycorrhizal fungal communities accompanying forest trees in different environmental conditions. Her studies have involved, among other topics, chronosequences of fungi accompanying Scots pine and European larch, the influence of tree genotype and environment on mycorrhizal communities of Scots pine and poplars, and the diversity of fungi associated with alien tree species. In recent years, Prof. Rudawska's research has focused on studies of fungal communities in protected and managed mixed coniferous forests. Professor Rudawaska's research has determined that the species composition of fungal communities is largely similar between forest reserves and managed forests, and only a small pool of species are unique to one of the stand types. Such results suggest that forest reserves as well as managed forests contribute to maintaining fungal diversity. 
For several years, Prof. Rudawska has taken particular interest in ectomycorrhizal fungi associated with tree seedlings. She has conducted several studies on the diversity of ectomycorrhizal fungi in bare-root forest nurseries, and her results have been published as a series of 13 scientific papers. Her research clearly evinces that seedlings of forest tree species such as Scot pine, Norway spruce, European larch, oaks, European beech, silver birch, European hornbeam, and small-leaved lime produced in bare-root forest nurseries are well colonized by ectomycorrhizal fungi, and these fungal communities are characterized by high species diversity. Over many years of research, Prof. Rudawska's efforts have contributed to the identification of more than 80 species of fungi in Polish forest nurseries.

During her many years of work at the Institute of Dendrology, Prof. Rudawska has played various roles: She was head of the Institute's Physiology Department and head of the Laboratory of Mycorrhizal Research. Currently, she heads the Laboratory of Symbiotic Associations. She has also served as deputy chairman of the Scientific Council of the Institute of Dendrology for several terms. Professor Rudawska will be remembered at the Institute of Dendrology not only for her research, but also as a generous team player; she founded a mycorrhizal group with talented contributors that now extends through multiple generations of researchers, all still contributing to her fondest interests - mycology, symbiosis and plant physiology, and biochemistry.

While working in Kórnik, Prof. Rudawska participated in numerous scientific internships abroad at a wide array of institutions, including the Institute of Experimental Botany of the Czechoslovak Academy of Sciences, Praha, Czechoslovakia; Institute of Landscape Ecology, Pruhonice, Czechoslovakia; Finnish Forest Research Institute, Helsinki, Finland; Swedish University of Agricultural Sciences Department of Forest Mycology and Pathology, Uppsala, Sweden; INRAFlore Pathogene, Dijon, France; and Slovenian Forestry Institute, Ljubljana, Slovenia.

Professor Rudawska has been tremendously successful in securing funds for scientific research. She has managed many research projects financed by the Foundation for Polish Science, the National Fund for Environmental Protection and Water Management, the State Committee for Scientific Research, the Ministry of Science, the National Science Center, as well as the General Directorate of the State Forests.

Professor Rudawska's numerous academic achievements include more than 80 original scientific papers, published mostly in recognized international peerreviewed scientific journals such as New Phytologist, Mycorrhiza, Forest Ecology and Management, Fungal Ecology, Annals of Forest Sciences, Physiologia Plantarum, Chemosphere, Environmental Pollution, Applied and Environmental Microbiology, and Microbial Ecology and indexed by Clarivate Analytics (Web of Science) and Scopus. A vital aspect of Prof. Rudawska's scientific activity is her long-standing cooperation with Dr. Algis Aučina from the Botanical Garden of Vilnius University, Lithuania, resulting in many scientific papers. Prof. Rudawska is also the author of numerous popular science publications and chapters in monographs, including chapters on mycorrhiza of Scots pine, Norway spruce, European beech, oaks, and elms published by the Institute of Dendrology in forest tree monographs. During her scientific career, she has actively participated in more than 50 international conferences, including all the European Symposia on Mycorrhizae, most International Conferences on Mycorrhizae, and three Congresses of European Mycologists. Professor Rudawska was also an active member of several Cost Actions focused on fungal belowground biodiversity.

Professor Rudawska has supervised four doctoral theses, nine master's theses, and three bachelor's theses. She has been a reviewer for more than 30 doctoral theses, habilitation dissertations, and professorship proceedings and more than 80 manuscripts submitted to scientific journals. Owing to her scientific acumen and experience, Professor Rudawska is often invited to review scientific projects for various domestic and foreign entities. For many years, she has worked as an independent expert and rapporteur at the European Commission (FP7, H2020). Although Prof. Rudawska's work at the scientific Institute does not involve direct teaching responsibilities, she has always been generous with her time for students 
and repeatedly presented guest lectures and laboratory classes for students of forestry and biology visiting the Institute of Dendrology.

As a result of her significant scientific achievements and contributions, Prof. Rudawska was awarded the title of full professor in biological sciences by the President of the Republic of Poland, Lech Kaczyński, in a ceremony held at the Presidential Palace on June 8, 2006.

Professor Rudawska is a member of many scientific societies including the Polish Mycological Society (founding member), the Polish Forestry Society, the European Mycological Association, and the Federation of European Society of Plant Physiologists. She is also an active member of the Mycological Section of the Polish Botanical Society where she served as the Secretary of the Poznan Division of the Section for several years, and as Chairperson of the Mycology Section from 2010 to 2016. From 2014 to 2018, she was also the Editor-in-Chief of the journal Acta Mycologica. At that time, Acta Mycologica became one of the publications indexed by the Scopus database. She is also a member of the National Committee on Forestry Sciences and Wood Technology of the Polish Academy of Sciences and the Committee on Forestry Sciences and Wood Technology of the Polish Academy of Sciences - Poznań Branch.

In her professional life, Prof. Rudawska has constantly been guided by one basic principle: Regardless of the situation, you should be a decent person, and always try to do the best job you can. In her personal life, Prof. Rudawska is a very active traveler and a great lover of the Baltic Sea and of flowers; her immense passion for classical music led her to bestow her dog with the mellifluous name Bemol. She is a mother to three sons, and a happy grandmother to five grandchildren - two girls and three boys. 